\title{
Supply-Based Strategies, Human Resource Initiatives, Procurement Leadtime, and Firm Performance
}

By Jayanth Jayaram and Shawnee K. Vickery

Jayanth Jayaram is a Doctoral Candidate in Operations Management at Michigan State University in the Eli Broad Graduate School of Management. He earned his M.B.A. degree from Central Michigan University. Mr. Jayaram's current research focuses on supply chain management, strategic purchasing, new product development, and time-based competition.

Shawnee K. Vickery is a Professor of Operations Management in the Eli Broad Graduate School of Michigan State University. Dr. Vickery earned her M.S. and Ph.D. degrees from the University of South Carolina. Dr. Vickery's research and teaching interests include operations management and management science.
International Journal of Purchasing and Materials Management $\odot$ Copyright January 1998 , by the National Association of Purchasing Management, Inc.

\section{IN BRIEF}

The role of procurement leadtime (PLT) in time-based competition (TBC) has received little attention in procurement and operations literature. This article examines the relationship of procurement leadtime to overall firm performance and identifies key antecedents of procurement leadtime performance. The research focuses on first-tier suppliers to the "Big 3" automobile manufacturers in North America. Linkages among supply-based strategies, human resource (HR) initiatives, procurement leadtime performance, and overall business performance are tested empirically. The study shows that procurement leadtime is significantly related to overall firm performance, especially market share and market share growth. The supply-based strategy of standardization and the HR strategy of employee empowerment are shown to be key drivers of procurement leadtime performance. Also, the combined use of these strategies is shown to have a synergistic effect on procurement leadtime.

\section{INTRODUCTION}

$\mathrm{T}$ ime-based strategies have been widely employed to achieve a variety of time-based performance goals. Such goals have typically included reductions in leadtimes for product development, product launch, manufacturing, and delivery. ${ }^{1}$ For example, $3 \mathrm{M}$ reduced its new product development time from two years to two months, Motorola cut its production lead time for cellular phones from several weeks to four hours, and Johnson and Johnson has the top selling contact lens largely due to its rapid (three days or less) and reliable (99.99 percent on-time) delivery of disposable contacts.

Improvements in time-based performance are not limited to new product development, manufacturing, and delivery. For example, Levi Strauss reduced its reorder cycle time from nine weeks to four days resulting in lower costs, fewer stockouts, and higher flexibility. ${ }^{2}$ This suggests that procurement leadtime is also an important dimension of time-based performance, even though it has received little attention in time-based literature.

The purpose of this research is three-fold. First, it examines the contribution of procurement leadtime (PTL) performance to overall firm 
performance using data from a large sample of companies in the automotive supply industry. Second, it examines the relationship between antecedents (or drivers) of procurement leadtime performance and procurement leadtime using data from the same sample of firms. Two major categories of antecedents are considered: (1) supplybased strategies; and (2) time-related "best practice" human resource (HR) initiatives. Finally, it investigates whether supply-based strategies and human resource initiatives interact in their effects on procurement leadtimes.

\section{LITERATURE REVIEW}

\section{Procurement Leadtime and Overall Business Performance}

Researchers have considered time-based competition relative to various stages of the overall value delivery system and have proposed a variety of measures to evaluate these different aspects of time-based performance. In the time-based competition (TBC) literature, five measures appear most frequently:

- Delivery speed

- New product development time

- Delivery reliability/dependability

- New product introduction

- Manufacturing leadtime

The popularity of these measures suggests that new product development, new product introduction, manufacturing, and delivery are key activities contributing to time-based performance. While strategic initiatives associated with procurement leadtime performance are described in the operations and sourcing literatures, the contribution of procurement leadtime to overall firm performance has been largely ignored. ${ }^{3}$ No empirical studies have examined the relationship of procurement leadtime to overall firm performance. We contend that procurement leadtime performance will exhibit a positive relationship with one or more measures of overall firm performance (e.g., ROI). This leads to the following proposition:

Research Proposition 1: There is a positive relationship between procurement leadtime performance and one or more measures of overall business performance (e.g., ROI).

\section{Supply-Based Strategies and Procurement Leadtime}

The operations and sourcing literature suggests that supply-based strategies affect time-based performance in general. Such strategies include electronic data interchange (EDI), integrating information systems, Just-In-Time (JIT) manufacturing/ purchasing, standardization, supplier development, and supplier partnership. A summary of the relevant literature is provided in Table I (see page 14). ${ }^{4}$ Note that this table highlights the nine empirical studies reporting statistically significant relationships between the use of supply-based strategies and timebased performance.

The literature reveals that the integration of information systems is a significant predictor of delivery and new product development leadtimes. For instance, Roth et al. found that lateral information systems and manufacturing informa tion systems had a significant positive impact on delivery speed for European and Japanese firms. ${ }^{5}$ De Meyer and Ferdows reported significant $t$-values $($ at $\mathrm{p}<0.05)$ in a study that compared scores on new product development speed between users and non-users of manufacturing information systems. ${ }^{6}$

JIT purchasing and JIT manufacturing have also been cited as key antecedents of time-based performance. In a study of high tech firms, Hendrick demonstrated that JIT purchasing was highly related to a composite measure of time-based performance. ${ }^{7}$ Similarly, De Meyer and Ferdows reported significant regression coefficients (at $\mathrm{p}<0.10$ ) for stepwise regressions of JIT manufacturing on delivery speed and JIT manufacturing on on-time delivery. ${ }^{8}$

The supply-based strategies of supplier development and supplier partnering have also been identified as significant antecedents to time-based p e rformance. Roth et al. found that supplier development had a highly significant relationship with delivery speed for Japanese firms. ${ }^{9}$ Another study compared scores on new product development speed between users and non-users of supplier development practices and found significant differences (at $\mathrm{p}<0.05) .{ }^{10}$ Finally, Hendrick found a positive relationship (at $\mathrm{p}<0.05$ ) between supplier partnering and a composite measure of time-based performance in a sample of high-tech firms. ${ }^{11}$

The supply-based strategies of electronic data interchange (EDI) and standardization have also been touted in the TBC literature as strongly influencing leadtime performance (see Table I page 14), even though empirical evidence is lacking. The purchasing literature also emphasizes the importance of EDI and standardization. In a recent survey, North American purchasing executives ranked electronic data interchange fifth out of 36 strategic items that were likely to be emphasized over the next five years. ${ }^{12}$ Also, Ellram and Pearson found that purchasing professionals ranked the responsibility of purchasing for standardization second to the highest in terms of projected future responsibility of purchasing in strategic decision-making. ${ }^{13}$

All of the empirical studies cited earlier examined the effects of supply-based strategies on on-time delivery, delivery speed, new product development speed, and a composite measure of time-based performance. No study considered the 
TABLE I

SUMMARY OF RELEVANT LITERATURE — SUPPLY-BASED STRATEGIES ${ }^{1}$

\begin{tabular}{|c|c|c|c|c|c|c|}
\hline & \multicolumn{6}{|c|}{ SUPPLY-BASED STRATEGY } \\
\hline & EDI & \begin{tabular}{|} 
Integrating \\
Information \\
Systems
\end{tabular} & $\begin{array}{c}\text { JIT } \\
\text { Manufacturing/ } \\
\text { Purchasing }\end{array}$ & Standardization & $\begin{array}{c}\text { Supplier } \\
\text { Development }\end{array}$ & $\begin{array}{c}\text { Supplier } \\
\text { Partnership }\end{array}$ \\
\hline Frequency Count & 3 & 9 & 9 & 4 & 11 & 4 \\
\hline De Meyer \& Ferdows '87 & & $x$ & & & & \\
\hline Ward et al. '88 & & $x$ & & & & \\
\hline De Meyer et al. '89 & & $x$ & & & $x$ & \\
\hline Roth et al. '89 & & $x$ & & & $x$ & \\
\hline De Meyer \& Ferdows '90 & & $x$ & $x$ & & $x$ & \\
\hline Ferdows \& De Meyer '90 & & $x$ & & & $x$ & \\
\hline Raturi et al. '90 & & & & $x$ & $x$ & \\
\hline Roth \& Miller '90 & & $x$ & $x$ & & $x$ & \\
\hline Ellram '91 & & & & & & $x$ \\
\hline Handfield '92 & & & & $x$ & & \\
\hline Mabert et al. '92 & & & & & $x$ & \\
\hline Lamming '93 & & & & & & $x$ \\
\hline Roth \& Maruchek '93 & & & $x$ & & $x$ & \\
\hline Tunc and Gupta '93 & & & $\mathrm{x}$ & & & \\
\hline Hendrick '94 & $x$ & & $x$ & & & $\mathrm{x}$ \\
\hline Hines '94 & & & & & & $x$ \\
\hline Kim '94 & & $x$ & & & $x$ & \\
\hline Zirger '94 & & $x$ & & $x$ & $x$ & \\
\hline Carter et al. '95 & $\mathrm{x}$ & & $\mathrm{x}$ & $x$ & & \\
\hline Handfield '95 & $x$ & & $x$ & & & \\
\hline Koufteros '95 & & & & & $x$ & \\
\hline Vickery '95 & & & $x$ & & & \\
\hline Youssef '95 & & & $\mathrm{x}$ & & & \\
\hline
\end{tabular}

'Note: Empirical studies identifying statistically significant relationships are designated by bold squares.

impact of supply-based strategies on procurement leadtimes. Yet one would expect supply-based strategies to have more of an impact on procurement leadtime than any other leadtime measure. In view of this, we advance the following proposition:

Research Proposition 2: There is a positive relationship between the use of one or more supplybased strategies (e.g., EDI) and procurement leadtime performance.

\section{Human Resource Initiatives and Procurement Leadtime}

Recent purchasing literature emphasizes the importance of human resource initiatives to purchasing performance. A recent Center of Advanced Purchasing Studies (CAPS) survey revealed that several companies use horizontal cross-functional teams to achieve "lean" purchasing organization structures. ${ }^{14}$ Another recent study found that several organizations have resorted to team decision making instead of individual decision making for problem solving with suppliers, supplier selection, make-or-buy decisions, and standardization efforts. ${ }^{15}$ Hult and Nichols found that cross-functional teams, JIT training, and empowerment were important activities that engendered the development of a learning buyer organization within the purchasing function. ${ }^{16}$

The operations literature suggests that human resource-related strategies can significantly affect time-based performance. Table II provides a summary of the literature relating human resource initiatives to time-based performance. ${ }^{17}$ As can be seen from Table II, all of the human resource initiatives contained in the table exhibited statistically significant relationships with one or more measures of time-based performance.

De Meyer and Ferdows found significant relationships between several human resource initiatives and time-based performance. ${ }^{18}$ Broad jobs, the use of crossfunctional teams, employee autonomy (giving workers more planning responsibility), and training were all positively related to product development speed 
SUMMARY OF RELEVANT TBC LITERATURE - HUMAN RESOURCE INITIATIVES AFFECTING TIME-BASED PERFORMANCE ${ }^{1}$

\begin{tabular}{|c|c|c|c|c|c|c|c|c|}
\hline & \multicolumn{8}{|c|}{ HR INITIATIVES } \\
\hline & $\begin{array}{c}\text { Broad } \\
\text { Jobs }\end{array}$ & $\begin{array}{c}\begin{array}{c}\text { Commun- } \\
\text { ication of } \\
\text { Goals }\end{array} \\
\end{array}$ & \begin{tabular}{|c|} 
Cross- \\
Functional \\
Teams
\end{tabular} & $\begin{array}{l}\text { Cross } \\
\text { Training }\end{array}$ & $\begin{array}{l}\text { Employee } \\
\text { Autonomy }\end{array}$ & $\begin{array}{c}\text { Employee } \\
\text { Impact }\end{array}$ & $\begin{array}{c}\text { Labor } \\
\text { Relations }\end{array}$ & Training \\
\hline Frequency Count & 8 & 4 & 8 & 2 & 8 & 5 & 6 & 10 \\
\hline Bower \& Hout '88 & & & $\mathrm{X}$ & & & & & $\mathrm{X}$ \\
\hline De Meyer \& Ferdows '90 & $\mathrm{X}$ & & $\mathrm{X}$ & & $\mathrm{X}$ & & & $\mathrm{X}$ \\
\hline De Meyer et al. '89 & $\mathrm{X}$ & & & & & & & \\
\hline Ferdows \& De Meyer '90 & & & & & $\mathrm{X}$ & & & \\
\hline Handfield '92 & & & & $x$ & & & & \\
\hline Handfield '95 & & & $\mathrm{X}$ & & & & & $\mathrm{X}$ \\
\hline Hendrick '94 & & $\mathrm{X}$ & $\mathrm{X}$ & $\mathrm{X}$ & & $x$ & & $\mathrm{X}$ \\
\hline Koufteros '95 & & & $\mathrm{X}$ & & $x$ & $\mathrm{X}$ & & \\
\hline Kim '94 & & & $\mathrm{X}$ & & $\mathrm{X}$ & & & $\mathrm{X}$ \\
\hline Miller \& Roth '94 & & & & & & & $x$ & \\
\hline Rosenthal \& Tatikonda '93 & & $x$ & & & & & & \\
\hline Roth et al. '89 & $\mathrm{X}$ & & & & & & $X$ & \\
\hline Roth \& Miller '90 & $\mathrm{X}$ & & & & & & $X$ & $x$ \\
\hline Roth \& Maruchek '93 & $x$ & & & & & & $x$ & $x$ \\
\hline Tunalv '92 & $\mathrm{X}$ & & & & $\mathrm{X}$ & & & $\mathrm{X}$ \\
\hline Tunc and Gupta '93 & & & & & & $x$ & & \\
\hline Vickery '95 & & $x$ & $x$ & & & $x$ & & \\
\hline Ward et al. ' 88 & $\mathrm{X}$ & & & & $\mathrm{X}$ & $\mathrm{X}$ & $\mathrm{X}$ & $\mathrm{X}$ \\
\hline Ward et al. '94 & $\mathrm{X}$ & & & & $x$ & & $x$ & $X$ \\
\hline Zirger and Hartley '94 & & $x$ & $x$ & & $x$ & & & \\
\hline
\end{tabular}

${ }^{1}$ Note: Empirical studies identifying statistically significant relationships are designated by bold squares.

$(p<0.10)$. Also, the use of cross functional teams was positively related to on-time delivery $(\mathrm{p}<0.10)$.

In a more recent study, Hendrick found that the communication of cycle time related goals, the use of multifunctional teams (including suppliers), and the use of cross training had significant, positive effects on a composite measure of time based performance. ${ }^{19}$ Hendrick also found significant differences between firms in high tech industries and firms in manufacturing industries in achieving cycle time reduction from the use of training. Similar significant differences between subsamples of firms in manufacturing and service were also reported.

Roth et al. found that broad jobs were positively related to delivery speed $(p=0.05)$ for Japanese firms. ${ }^{20}$ More recently, Koufteros found the use of cross functional teams to be positively related to product development time $(p<0.05) .{ }^{21}$ Similarly, Koufteros' study showed that employee involvement was positively related to manufacturing lead time $(\mathrm{p}<0.05)$.

These studies reveal that human resource initiatives can significantly impact time based performance, especially on-time delivery, delivery speed, and new product development speed. While no empirical evidence exists, it is reasonable to assume that these strategies might also affect procurement lead time. However, this expectation must be tempered with the realization that certain HR strategies are more germane to the purchasing function than others (e.g., cross-functional teams versus labor relations). The HR strategies that are most likely to be relevant to the procurement function, and procurement leadtime in particular, are:

- Communication of goals

- Cross-functional teams

- Employee training

- Employee empowerment (which encompasses both employee autonomy and employee impact)

Three of these four items (teams, training, and employee empowerment) are identified as "best practices" in the human resources literature. ${ }^{22}$ With this in mind, we contend that cross-functional teams for TBC, employee training for TBC, and employee empowerment will positively impact procurement 
FIGURE 1

A MODEL LINKING SUPPLY-BASED STRATEGIES, HUMAN RESOURCE-RELATED STRATEGIES, AND THEIR INTERACTION TO PROCURMENT LEADTIME PERFORMANCE

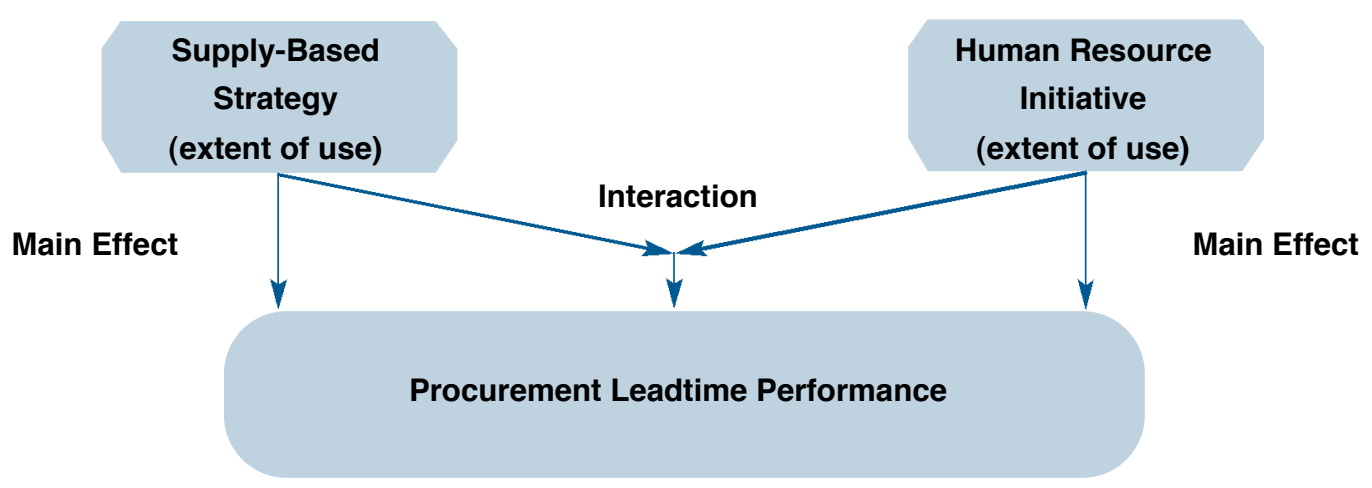

leadtimes. (Since communication of goals is not considered a best practice HR initiative, it was excluded from further consideration.) This leads to the following proposition:

Research Proposition 3: There is a positive relationship between the use of one or more relevant, "best practice" human resource strategies (e.g., empowerment) and procurement leadtime performance.

\section{Supply-Based Strategies, Human Resource Initiatives, and Procurement Leadtimes}

Supply-based strategies and human resource initiatives may be synergistic in their impact on procurement leadtimes. Hence, we propose a conceptual model to describe the general relationship of supply-based strategies, human resource initiatives, and procurement leadtime performance (Figure 1). The model indicates that a given supplybased strategy and an associated human resource initiative may each directly affect procurement leadtime performance, but that they may also interact in their impact on procurement leadtime. For example, the model indicates that JIT purchasing and empowerment may both individually affect procurement lead time but that they may also interact in their effects on procurement leadtime performance.

\section{RESEARCH METHODOLOGY}

The Sampling Procedure and Sample

The study focused on first-tier suppliers to the "Big 3" North American automobile manufacturers. The population frame consisted of the top 150 first tier suppliers to the Big 3 (in terms of annual sales). The list of companies comprising the population frame was provided by industry experts from the Automotive Industry Action Group (AIAG). The AIAG is a professional association with over 1,000 members including the Big $3 .^{23}$
Several attributes of the automotive supplier industry made it an attractive subject for study. First, time-based competition has played a vital role in the automobile industry - the industry has already been the focus of at least one time-related empirical study. ${ }^{24}$ Second, first tier suppliers are more likely than lower tier suppliers to be actively engaged in human resource and supply-based initiatives aimed at improving competitive performance (time-related or otherwise) since they are under significant pressure from OEMs to upgrade their competitive programs and methods.

The research questionnaire, accompanied by an informational letter, was mailed to the CEOs of all firms included in the population frame. CEOs of strategic business units (SBUs) or individual firms were instructed to complete the survey for their SBU or firms. CEOs of multiple business units were instructed to select one of their SBUs to participate in the study and to forward the research questionnaire to the CEO of that unit. Several follow-up telephone calls were made to obtain definitive responses from CEOs regarding their participation in the study.

The final sample for the study consisted of 57 firms. The response rate was approximately 39 percent. Mean sales for the sample was $\$ 501,516,415$ with a standard deviation of $\$ 637.46$ million. The mean number of employees was $2,810.99$ with a standard deviation of 3,431.07. All data pertained to 1995 .

\section{Measurement Issues}

Validation of the Research Questionnaire. The unit of analysis was the individual firm or strategic business unit (SBU) involved in manufacturing and selling automotive systems/components to the Big 3. A panel of experts from AIAG assisted in ensuring the content validity of the research questionnaire.

To increase face validity, most of the items appearing in the survey instrument were defined. 
The expert panel reviewed the definitions of terms used in the questionnaire and recommended changes to ensure there were no items with ambiguous meanings or multiple interpretations. In some cases, they provided definitions (e.g., supplier partnering).

Procurement Leadtime Measurement. The respondents were asked to rate the importance of procurement leadtime using a seven-point scale with endpoints "Least Important" (1) and "Extremely Important" (7). In a similar fashion, the respondents were asked to provide a seven-point rating of the firm's performance relative to its major competitors for procurement leadtime, where 1 represented "Poor" and 7 represented "Excellent." Past research has found that managerial assessments such as these are consistent with objective internal performance ${ }^{25}$ and even with external secondary data. ${ }^{26}$

Measurement of "Extent of Use" of SupplyBased Strategies. The survey instrument measured the extent of use of seven supply-based strategies:

1. Electronic data interchange

2. Integrating information systems

3. JIT manufacturing

4. JIT purchasing

5. Standardization

6. Supplier development

7. Supplier partnership

Definitions for these items as they appeared in the research questionnaire are provided in Appendix 1. Respondents were asked to indicate the extent to which each of these programs was used by the firm to support its overall business strategy. If an action program was not used by a firm of SBU, the respondent was asked to circle "Not Used." The extent of use scale was a seven-point scale with endpoints labeled "Extremely Low Use of Item" (1) and "Extremely High Use of Item" (7).

Note that the literature is not consistent in its treatment of JIT manufacturing and JIT purchasing as separate constructs or as a single construct. We separated these two practices to facilitate comparison of our results to purchasing research which has treated JIT purchasing as distinct from JIT manufacturing. ${ }^{27}$

Means, standard deviations, and sample sizes for the extent of use ratings for the seven supplybased strategy items are presented in Table III (Part A). The correlation matrix for these items and others is shown in Appendix 2 (see page 23). As can be seen from the correlation matrix in Appendix 2, the extents of usage for the supply-based strategies are, in some cases, highly correlated.

Measurement of "Extent of Use" of Human Resource Initiatives. The extent of use of the best practice human resource initiatives was measured on a seven-point scale. The respondents were asked to indicate the extent to which each of these human resource initiatives was used by the firm. The extent of use scale was a seven-point scale with endpoints "Extremely Low Use of Item" (1) and "Extremely High Use of Item" (7).

Since employee autonomy and employee impact are underlying dimensions of employee empowerment, these items were separately measured on a seven-point scale and later collapsed into one overall construct - employee empowerment. ${ }^{28}$ Means,

TABLE III

MEANS FOR TIME-RELATED SUPPLY-BASED STRATEGIES AND HUMAN RESOURCE INITIATIVES EXTENT OF USE SCORES ( 1 to 7 scale)

\begin{tabular}{|c|c|c|c|}
\hline PART A: SUPPLY-BASED STRATEGIES ${ }^{1}$ & Means & Standard Deviation & $\mathbf{n}$ \\
\hline EDI & 4.80 & 1.39 & 56 \\
\hline Integrating Information Systems & 4.69 & 1.40 & 54 \\
\hline JIT Manufacturing & 5.13 & 1.41 & 55 \\
\hline JIT Purchasing & 4.67 & 1.39 & 55 \\
\hline Standardization & 5.15 & 1.34 & 55 \\
\hline Supplier Development & 4.61 & 1.30 & 56 \\
\hline Supplier Partnership & 4.82 & 1.25 & 56 \\
\hline \multicolumn{4}{|l|}{ PART B: HUMAN RESOURCE INITIATIVES ${ }^{2}$} \\
\hline Cross Functional Teams for TBC & 4.24 & 1.49 & 57 \\
\hline Employee Training - TBC & 3.98 & 1.48 & 57 \\
\hline Employee Empowerment & 4.91 & 1.08 & 54 \\
\hline
\end{tabular}

Notes: ${ }^{1}$ One-way ANOVA indicates no significant difference in the mean extent of use ratings at a 0.05 level of significance. ${ }^{2}$ One-way ANOVA indicates a significant difference in the mean extent of use ratings at a 0.05 level of significance. Multiple range tests (Bonferroni and Scheffe) indicate mean extent of use ratings for employee empowerment is different from mean extent of use ratings for other human resource initiatives at a 0.05 level of significance. 
standard deviations, and sample sizes for the three HR items, cross-functional teams for TBC, training for TBC, and employee empowerment, are presented in Table IV (Part B). The correlation matrix for these items, and others as well is provided in Appendix 2. As can be seen from Table IV, Part B, the use of empowerment by first-tier suppliers is significantly greater than the use of the other HR strategies. Furthermore, the correlation matrix in Appendix 2 indicates that the degrees of use of the human resource initiatives are highly correlated.

Overal Business Performance Measurement. Overall business performance was evaluated using the following six financial and marketing measures:

1. Pretax Return on Assets (Pretax ROA)

2. After Return on Assets (Aftertax ROA)

3. Return on Investment (ROI)

4. Market Share

5. Growth in ROI

6. Growth in Market Share

For each measure, CEO respondents provided a subjective rating of the firm's performance relative to its major industry competitors on a seven-point scale with endpoints labeled "Worst in Industry" (1) and "Best in Industry" (7). Actual values for each of these overall firm performance measures were also obtained from those CEOs willing to release such sensitive information. About onethird of the CEOs complied.
The means and the sample sizes for both the subjective ratings and the actual values for the six overall business performance measures are provided in Table IV. Note that the sample sizes for the actual values are much smaller than those of the subjective measures due to the unwillingness of many CEOs to release sensitive financial information.

In Table IV, the correlations of the subjective ratings and actual values are provided for each overall firm performance measure. For example, the correlation between the subjective rating and the actual value for Market Share is 0.4868 ; the correlation between the subjective rating and the actual value for Pretax ROA is 0.6113; and the correlation between the subjective rating and the actual value for Aftertax ROA is 0.6462. P-values for each correlation are also provided. The p-values for each correlation are for a one-tail test with null hypothesis, $\mathrm{H}_{0}: \mathrm{p} \leq 0$. All correlations are statistically significant at the 0.05 (i.e., $\rho>0$ ) except for ROI which is marginally significant. The results demonstrate that the subjective ratings are highly reliable indicators of the actual values. The subjective ratings are used in all subsequent analyses to take advantage of the larger sample sizes associated with them.

\section{RESULTS AND DISCUSSION}

\section{Procurement Leadtime Performance and Overall Firm Performance}

A series of regression analyses were used to test Research Proposition 1. Table V presents the results

TABLE IV

MEANS AND INTERCORRELATIONS OF THE PERFORMANCE MEASUREMENTS
\begin{tabular}{|l|c|c|c|c|c|c|}
\hline & & & Standard \\
Performance Measure & $\mathbf{n}$ & Mean & Deviation & Intercorrelations & $\begin{array}{c}\text { p-value } \\
\text { (one-tail) }\end{array}$ \\
\hline 1. Market Share & & & & & & \\
\hline A: Subjective Rating & 52 & 4.8462 & 1.5131 & - & & \\
\hline B: Actual Market Share & 32 & 24.7031 & 19.0715 & 0.4868 & - & 0.002 \\
\hline 2. Pretax ROA & & & & & & \\
\hline A: Subjective Rating & 52 & 4.9038 & 1.3760 & - & & \\
\hline B: Actual ROA (Pre-tax) & 27 & 18.7370 & 12.7840 & 0.6113 & - & 0.0004 \\
\hline 3. After-tax ROA & & & & & & \\
\hline A: Subjective Rating & 52 & 4.9615 & 1.3130 & - & & \\
\hline B: Actual ROA (After tax) & 23 & 12.3522 & 8.6200 & 0.6462 & - & 0.0005 \\
\hline 4. ROI & & & & & & \\
\hline A: Subjective Rating & 51 & 5.0784 & 1.3091 & - & & \\
\hline B. Actual ROI & 23 & 25.6443 & 36.2970 & 0.3139 & - & 0.0724 \\
\hline 5. Growth in ROI & & & & & & \\
\hline A: Subjective Rating & 53 & 4.5283 & 1.3812 & - & & \\
\hline B. Actual Growth - ROI & 23 & -0.1425 & 0.4231 & 0.6886 & - & 0.0002 \\
\hline 6. Growth in Market Share & & & & & & \\
\hline A: Subjective Rating & 55 & 4.8182 & 1.3621 & - & & \\
\hline B: Actual Growth - Market Share & 31 & 0.0753 & 0.1093 & 0.3383 & - & 0.0313 \\
\hline
\end{tabular}




\section{ORDINARY REGRESSION ANALYSIS OF PROCUREMENT LEADTIME PERFORMANCE ON BUSINESS PERFORMANCE}

\begin{tabular}{|c|c|c|c|c|}
\hline \multirow{2}{*}{$\begin{array}{c}\text { Business Performance } \\
\text { Measure } \\
\text { (Dependent Variable) }\end{array}$} & \multicolumn{4}{|c|}{$\begin{array}{c}\text { Procurement Leadtime Performance } \\
\text { (Independent Variable) }\end{array}$} \\
\cline { 2 - 5 } & $\begin{array}{c}\text { Sample } \\
\text { Size }\end{array}$ & $\mathbf{R}^{2}$ & $\begin{array}{c}\text { Regression } \\
\text { Coefficient }\end{array}$ & $\begin{array}{c}\text { p-value } \\
\text { (1-tailed) }\end{array}$ \\
\hline ROA (pre-tax) & 52 & 0.0589 & 0.2427 & 0.0415 \\
\hline ROA (after tax) & 52 & 0.0558 & 0.2362 & 0.0460 \\
\hline ROI & 51 & 0.0410 & 0.2024 & 0.0770 \\
\hline Market Share & 52 & 0.0922 & 0.3037 & 0.0145 \\
\hline Growth - ROI & 53 & 0.0521 & 0.2282 & 0.0500 \\
\hline Growth - Market Share & 55 & 0.0605 & 0.2460 & 0.0350 \\
\hline
\end{tabular}

of the simple linear regressions of procurement leadtime performance (independent variable) on each of the six business performance measures (dependent variable). For each regression analysis, the sample size, the model $\mathrm{R}^{2}$, the standardized regression coefficient, and the p-value is reported. The p-value for each regression is for a one-tail test with null hypothesis, $H_{0}: \beta_{1} \leq 0$. The $p$-value for a one-tail test of the regression coefficient is of primary importance in testing Research Proposition 1. Recall that our measure of procurement leadtime does not represent actual leadtime or a change in leadtime but a CEO's perception of the company's procurement leadtime performance vis-a-vis major industry competitors.

As can be seen from Table $\mathrm{V}$, procurement leadtime is positively related to five of the six measures of bottomline firm performance at a 0.05 level of significance (i.e., $\mathrm{B}_{1}>0$ ). In particular, procurement leadtime is significantly related to Pre-tax ROA $(p=0.041)$, After tax ROA $(p=0.046)$, Market Share $(\mathrm{p}=0.014)$, ROI Growth $(\mathrm{p}=0.050)$, and Market Share Growth $(\mathrm{p}=0.035)$. It is intriguing that procurement leadtime exhibits the strongest relationships with Market Share and Market Share Growth. Overall, five of the six regression models are significant at the 0.05 level (or less) in comparison to the 0.3 that would be expected due to chance alone. Thus, Research Proposition 1 is supported.

\section{Supply-Based Strategies and Procurement Leadtime Performance}

Research Proposition 2 was tested using stepwise regression analysis. The stepwise procedure used was a modification of the forward selection modelbuilding procedure. An alpha value of 0.05 was chosen as the entry cut-off value. It should be noted that stepwise regression identifies independent variables(s) which explain additional variance in the dependent variable, given the variable(s) already in the model. Thus, it is possible that a significant predictor of PLT performance in ordinary regression might not enter the stepwise model.
The results of the stepwise regression of the seven supply-based strategies (independent variables) on procurement leadtime performance (dependent variable) are reported in Table VI (see page 20). The sample size, model p-value, adjusted $R^{2}$, regression coefficients, and $p$-values are provided. Note that the entry p-values reported in Table VI are for two-tail tests of significance of the regression coefficients (i.e., $\mathrm{H}_{0}: \beta_{i=0}$ ). Two-tail p-values are automatically reported by statistical packages for stepwise regression. As can be seen from Table VI, standardization was the only supply-based strategy to enter the stepwise model. Again, this does not mean that other supply-based strategies are not individually significant. Two of them are significantly correlated to PLT performance at a 0.05 level of significance - JIT Manufacturing and Supplier Partnership (see correlation matrix in Appendix 2). What the stepwise analysis reveals is that standardization by itself explains the greatest amount of variance in PLT performance. Thus, Research Proposition 2 is supported.

In the TBC literature, five supply-based strategies were significantly related to various timebased measures: integrating information systems, JIT manufacturing, JIT purchasing, supplier development, and supplier partnership. In our study, two of these five strategies are individually related to procurement leadtime performance (Appendix 2). The literature also suggested that EDI and standardization should positively impact time-based performance, although empirical evidence was lacking. In this study, standardization is highly correlated with PLT and by itself explains the greatest amount of the variance in PLT performance ( $\mathrm{p}$-value $\left.=0.0005 ; \mathrm{R}^{2}=0.2041\right)$. Contrary to expectations in the literature, we found EDI to be unrelated to PLT.

\section{Human Resource Initiatives and Procurement Leadtime Performance}

Research Proposition 3 was tested using stepwise regression analysis. The results of the stepwise 
regression analysis of the extents of use of "best practice" human resource initiatives (independent variables) on procurement leadtime performance (dependent variable) are reported in Table VII. Table VII reports the sample size, model p-value, adjusted $\mathrm{R}^{2}$, regression coefficients, and $\mathrm{p}$-values for entering variables. The $p$-values provided in Table VI correspond to two-tail tests of significance of the regression coefficients (i.e., $\mathrm{H}_{0}: \beta_{i=0}$ ). Stepwise regression analysis typically report twotail p-values. As can be seen from Table VII, empowerment was the only human resource initiative to enter the stepwise model. This does not mean that the other relevant best practice human resource initiatives are not individually significant; cross-functional teams is marginally significant at a 0.05 level of significance (Appendix 2). However, the stepwise results indicate that empowerment by itself explains the greatest amount of the variance in PLT performance ( $p$-value of $0.002 ; \mathrm{R}^{2}=0.1426$ ). Thus, Research proposition 3 is also supported.

\section{Interaction Effects}

To test the model in Figure 1, the supply-based strategy of standardization was considered in tandem with the human resource initiative of empowerment and analyzed using stepwise regression. The stepwise procedure used was the same forward selection model-building procedure with an alpha value of 0.05 as the entry cut-off value. Recall that stepwise regression identifies independent variable(s) which explain additional variance in the dependent variable, given the variable(s) already in the model. Table VIII provides the stepwise regression results.

As can be seen from Table VIII, only the interaction of standardization and employee empowerment enters the model. The standardization-empowerment interaction term is highly related to procurement leadtime performance $(\mathrm{p}=0.0001)$. The adjusted $\mathrm{R}^{2}$ for this stepwise model is 0.2568 . Thus standardization, used in tandem with empowerment, explains a significant portion of the variance in procurement leadtime. Note that the adjusted $\mathrm{R}^{2}$ for this model is much greater than the adjusted $\mathrm{R}^{2}$ for the stepwise model in which standardization appears alone (Table VI) and the adjusted $\mathrm{R}^{2}$ for the stepwise model in which empowerment appears alone (Table $\mathrm{V})$. The analysis indicates that the greatest improvement in PLT performance can be achieved by the joint use of standardization and empowerment. Overall, the results indicate that supplybased strategies and human resource initiatives can be synergistic in their impact on procurement leadtime performance.

\section{SUMMARY AND CONCLUSIONS}

This research focused on procurement leadtime as an important indicator of time-based performance. The study found that the subjective measure of procurement leadtime performance is significantly related to multiple subjective measures of business performance, especially market share related measures.

TABLE VI

STEPWISE REGRESSON ANALYSIS OF EXTENT OF USE OF SUPPLY-BASED STRATEGIES ON PROCUREMENT LEADTIME PERFORMANCE

\begin{tabular}{|c|c|c|c|c|c|c|}
\hline $\begin{array}{c}\text { Dependent } \\
\text { Variable }\end{array}$ & $\begin{array}{c}\text { Sample } \\
\text { Size }\end{array}$ & $\begin{array}{c}\text { Model p-value } \\
\text { (2-tailed) }\end{array}$ & $\begin{array}{c}\text { Adjusted } \\
\mathbf{R}^{\mathbf{2}}\end{array}$ & $\begin{array}{c}\text { Independent } \\
\text { Variables Entered }\end{array}$ & $\begin{array}{c}\text { Beta } \\
\text { Coefficient }\end{array}$ & $\begin{array}{c}\text { Entry p-value } \\
\text { (2-tailed) }\end{array}$ \\
\hline $\begin{array}{c}\text { Procurement lead- } \\
\text { time performance }\end{array}$ & 51 & 0.0005 & 0.2041 & Standardization & 0.4690 & 0.0005 \\
\hline
\end{tabular}

TABLE VII

STEPWISE REGRESSION ANALYSIS OF EXTENT OF USE OF HUMAN RESOURCE STRATEGIES ON PROCUREMENT LEADTIME PERFORMANCE

\begin{tabular}{|c|c|c|c|c|c|c|}
\hline $\begin{array}{c}\text { Dependent } \\
\text { Variable }\end{array}$ & $\begin{array}{c}\text { Sample } \\
\text { Size }\end{array}$ & $\begin{array}{c}\text { Model p-value } \\
\text { (2-tailed) }\end{array}$ & $\begin{array}{c}\text { Adjusted } \\
\mathbf{R}^{\mathbf{2}}\end{array}$ & $\begin{array}{c}\text { Independent } \\
\text { Variables Entered }\end{array}$ & $\begin{array}{c}\text { Beta } \\
\text { Coefficient }\end{array}$ & $\begin{array}{c}\text { Entry p-value } \\
\text { (2-tailed) }\end{array}$ \\
\hline $\begin{array}{c}\text { Procurement lead- } \\
\text { time performance }\end{array}$ & 54 & 0.0049 & 0.1261 & Empowerment & 0.3775 & 0.0049 \\
\hline
\end{tabular}

TABLE VIII

STEPWISE REGRESSON ANALYSIS OF STANDARDIZATION AND EMPOWERMENT (WITH INTERACTION TERM) ON PROCUREMENT LEADTIME PERFORMANCE

\begin{tabular}{|c|c|c|c|c|c|c|}
\hline $\begin{array}{c}\text { Dependent } \\
\text { Variable }\end{array}$ & $\begin{array}{c}\text { Sample } \\
\text { Size }\end{array}$ & $\begin{array}{c}\text { Model p-value } \\
\text { (2-tailed) }\end{array}$ & $\begin{array}{c}\text { Adjusted } \\
\mathbf{R}^{\mathbf{2}}\end{array}$ & $\begin{array}{c}\text { Independent } \\
\text { Variables Entered }\end{array}$ & $\begin{array}{c}\text { Beta } \\
\text { Coefficient }\end{array}$ & $\begin{array}{c}\text { Entry p-value } \\
\text { (2-tailed) }\end{array}$ \\
\hline $\begin{array}{c}\text { Procurement lead- } \\
\text { time performance }\end{array}$ & 52 & 0.0001 & 0.2568 & $\begin{array}{c}\text { Standardization } \mathrm{x} \\
\text { Empowerment }\end{array}$ & 0.5209 & 0.0001 \\
\hline
\end{tabular}


One supply-based strategy (standardization) and one human resource initiative (employee empowerment) are identified as critical antecedents of procurement leadtime performance. However, it is the combined use of these two that produces the greatest impact on PLT performance. From a managerial perspective, this suggests that the funneling of resources into standardization should be matched by an equal allocation of resources to employee empowerment.

Standardization, in combination with the HR initiative of empowerment, explains a significant portion of the variance in procurement leadtime performance (more than a fourth). This suggests that standardization in tandem with empowerment offers the "biggest bang for the buck" in improving procurement leadtimes. The implications for procurement strategy are straightforward. Any effort to reduce procurement leadtimes should include standardization combined with empowerment as the centerpiece of the effort.

\section{REFERENCES}

1. J.D. Blackburn, Time-based competition: The Next Battle ground in American Manufacturing (Homewood, IL: Business One Irwin, 1991); B.J. Zirger and J.L. Hartley, "A Conceptual Model of Product Development Cycle Time," Journal of Engineering Technology Management, vol. 11 (1994), pp. 229-251; L. Trygg, “Concurrent Engineering Practices in Selected Swedish Companies: A Movement or an Activity of the Few?," Journal of Product Innovation Management, vol. 10, no. 5 (1993), pp. 403-415.

2. T. Peters, "Tomorrow's Companies," The Economist, (March 4, 1989), pp. 19-22.

3. T.E. Hendrick, Purchasing's Contributions to Time Based Strategies (Tempe, AZ: Center for Advanced Purchasing Studies, 1994); J.S. Kim, "Beyond the Factory Walls: Overcoming Competitive Gridlock," Manufacturing Roundtable, Boston University, September 1994; A.V. Roth and A. Maruchek, "Defining World Class Manufacturing: An Exploratory Study In the Automotive/Transportation Industry," (University of North Carolina at Chapel Hill, Chapel Hill: NC, Working Paper, 1993).

4. A. De Meyer and K. Ferdows, "Managerial Focal Points in Manufacturing Strategy," International Journal of Pro duction Research, vol. 25, no. 11 (1987), pp. 1551-1562; P.T. Ward, J.G. Miller, and T.E. Vollmann, "Mapping Manufacturing Concerns and Action Plans," International Jour nal of Operations and Production Management, vol. 8, no. 6 (1988), pp. 5-18: A. De Meyer, J. Nakane, J.G. Miller, and K. Ferdows, "Flexibility: The Next Competitive Battle The Manufacturing Futures Survey," Strategic Manage ment Journal, vol. 10 (1989), pp. 135-144; A.V. Roth, A. De Meyer, and A. Amano, "International Manufacturing Strategies: A Comparative Analysis," Managing Interna tional Manufacturing, (Elsevier Science Publishers B.V. North-Holland, 1989), pp. 187-211; A. De Meyer and K. Ferdows, "Influence of Manufacturing Improvement Programs On Performance," International Journal of Oper ations and Production Management, vol. 10, no. 12 (1990), pp. 120-131; K. Ferdows and A. De Meyer, "Lasting Improvements In Manufacturing Performance: In Search of a New Theory," Journal of Operations Management, vol. 9, no. 2 (1990), pp. 168-184; A.S. Raturi, J.R. Meredith, D.M. McCutcheon, and J.D. Camm, "Coping with the Buildto-Forecast Environment," Journal of Operations Manage ment, vol. 9, no. 2 (1990), pp. 230-249; A.V. Roth and J.G. Miller, "Manufacturing Strategy, Manufacturing Strength, Managerial Success, and Economic Outcomes," Manufacturing Strategies (Boston: Kluwer Academic Pub., 1990), pp. 97-108; L.M. Ellram, “A Managerial Guideline for Development and Implementation of Purchasing Partnerships," International Journal of Purchasing and Materials Management, vol. 27, no. 3 (1991), pp. 2-8; R.B. Handfield, "An Empirical Speed of Delivery Speed and Reliability," International Journal of Operations and Production Management, vol. 12, no. 2 (1992), pp. 58-72; V.A. Mabert, J.F. Muth, and R.W. Schmenner, "Collapsing New Product Development Times: Six Case Studies," Journal of Product Innovation and Management, vol. 9 (1992), pp. 200-212; R. Lamming, Beyond Partnership: Strategies for Innovation and Lean Supply (Prentice Hall: Hemel Hempstead, 1993); Roth and Maruchek, op. cit., 1993; E.A. Tunc and J.N.D. Gupta, "Is Time a Competitive Weapon Among Manufacturing Firms?," Interna tional Journal of Operations and Production Management, vol. 13, no. 3 (1993), pp. 4-12; Hendrick, op. cit., 1994; P. Hines, Creating World Class Suppliers: Unlocking Mutual Competitive Advantage (London: Pitman Publishing, 1994); Kim, op. cit., 1994; Zirger and Hartley, op. cit., 1994: P.L. Carter, S.A. Melnyk, and R.B. Handfield, "Identifying the Basic Process Strategies for Time-Based Competition," Production and Inventory Management Jour nal, vol. 36, no. 1 (1995), pp. 65-70; R.B. Handfield, Reengineering for Time-Based Competition (Westport, CT: Quorum Books, 1995); X. Koufteros, "Time-Based Competition: Developing a Nomological Network of Constructs and Instrument Development," unpublished Ph.D. Dissertation, University of Toledo, June 1995; S.K. Vickery, C. Droge, J.M. Yeomans, and R.E. Markland, "Time-Based Competition in the Furniture Industry: An Empirical Study," Production and Inventory Management Journal, vol. 36, no. 4 (1995), pp. 14-21; M.A. Youssef, "Design for Manufacturability and Time-to-Market," International Journal of Operations and Production Management, vol. 15, no. 1 (1995), pp. 6-23.

5. Roth et al., op. cit., 1989.

6. De Meyer and Ferdows, op. cit., 1990.

7. Hendrick, op. cit., 1994.

8. De Meyer and Ferdows, op. cit., 1990.

9. Roth et al., op. cit., 1989.

10. De Meyer and Ferdows, op. cit., 1990.

11. Hendrick, op. cit., 1994.

12. J.R. Carter and R. Narasimhan, Purchasing and Supply Management: Future Directions and Trends (Tempe, AZ: Center for Advanced Purchasing Studies, 1995).

13. L.M. Ellram and J.N. Pearson, "The Role of the Purchasing Function: Toward Team Participation," International Journal of Purchasing and Materials Management, vol. 29, no. 3 (1993), pp. 3-9.

14. Carter and Narasimhan, op. cit., 1995.

15. Ellram and Pearson, op. cit., 1993.

16. G.T.M. Hult and E.L. Nichols "The Organizational Buyer Behavior Learning Organization," Industrial Mar keting Management, vol. 25 (1996), pp. 197-207.

17. J.L. Bower and T.M. Hout, "Fast Cycle Capability for Competitive Power," Harvard Business Review, (NovemberDecember 1988), pp. 110-118; De Meyer and Ferdows, op. cit., 1990; De Meyer et al., op. cit., 1989 Ferdows and De Meyer, op. cit., 1990; Handfield, op. cit., 1992; Handfield, op cit., 1995; Hendrick, op. cit., 1994 Koufteros, op. cit., 
1995; Kim, op. cit., 1994; J.G. Miller and A.V. Roth, “ A Taxonomy of Manufacturing Strategies," Management Sci ence, vol. 40, no. 3 (1994), pp. 285-304; S.R. Rosenthal and M.V. Tatikonda, "Time Management in New Product Development: Case Study Findings," IEEE Engineering Management Review, vol. 21, no. 3 (1993), pp. 13-20; Roth et al., op. cit., 1989; Roth and Miller, op. cit., 1990; Roth and Maruchek, op. cit, 1993; C. Tunalv, "Manufacturing Strategy - Plans and Business Performance," International Journal of Operations and Production Management, vol. 12 (1994), pp. 4-24; Tunc and Gupta, op. cit, 1993; Vickery et al, op. cit., 1995; Ward et al., op. cit., 1988; P.T. Ward, G.K. Leong, and K.K. Boyer, "Manufacturing Proactiveness and Performance," Decision Sciences, vol. 25, no. 3 (1994), pp. 337-355; Zirger and Hartley, op. cit., 1994.

18. De Meyer and Ferdows, op. cit., 1990.

19. Hendrick, op. cit., 1994.

20. Roth et al., op. cit., 1989.

21. Koufteros, op. cit., 1995.

22. M.A. Youndt, S.A. Snell, J.W. Dean, and D.P. Lepak, "Human Resource Management Manufacturing Strategy, and Firm Performance," Academy of Management Journal, vol. 39, no. 4 (1996), pp. 836-866.
23. "Strength in Numbers," Actionline, July 1995, p. 8.

24. J. Womack, D. Jones, and D. Roos, The Machine that Changed the World (New York: Rawson Associates, 1990)

25. G.S. Dess and R.B. Robinson, "Measuring Organizational Performance in the Absence of Objective Measures: A Case of the Privately-Held Firm and Conglomerate Business Unit," Straegic Management Journal, vol. 5, no. 3 (1984), pp. 265-273.

26. N. Venkatraman and V. Ramanujam, "Measurements of Business Performance in Strategy Research: A Comparison of Approaches," Academy of Management Review, vol. 11, no. 4 (1986), pp. 801-814.

27. A.Ansari and B. Modrass, "JIT Purchasing as a Quality and Productivity Centre," International Journal of Produc tion Research, vol. 26 (1988), pp. 19-26; C.K. Hahn, P.A. Pinto, and D.J. Bragg, "Just-In-Time Production and Purchasing," Journal of Purchasing and Materials Management, vol. 19, no. 3 (1983), pp. 2-10.

28. G.M. Spreitzer, "Psychological Empowerment in the Workplace: Dimensions, Measurement, and Validation," Academy of Management Journal, vol. 38, no. 5 (1995), pp. 1442-1465.

\section{SUPPLY-BASED STRATEGY DEFINITIONS}

1. INTEGRATED EDI: The integration of paperless (electronic) documents into business systems with no manual intervention.

2. INTEGRATED INFORMATION SYSTEMS: The use of information technology that enables all functional areas to access and transmit information from one area to another.

3. JIT MANUFACTURING: A philosophy of eliminating waste characterized by reduced set-up times and small lot sizes, in which components and products are pulled, as required, by the manufacturing system.

4. JIT PURCHASING: Requiring JIT deliveries from your suppliers to support your overall JIT strategy.

5. STANDARDIZATION: The use of standard procedures, materials, parts, and/or processes for designing and manufacturing a product.

6. SUPPLIER DEVELOPMENT: Policies, procedures, and practices for assessing and improving supplier capability and performance in multiple areas such as quality, design support, and delivery.

7. SUPPLIER PARTNERSHIP: Bringing all of the participants in the product life cycle into the process early on so suppliers and customers can provide input to each others' processes. 
CORRELATION MATRIX OF THE VARIABLES

\begin{tabular}{|c|c|c|c|c|c|c|c|c|c|c|c|c|c|c|c|c|c|c|}
\hline & Variables & & 1 & 2 & 3 & 4 & 5 & 6 & 7 & 8 & 9 & 10 & 11 & 12 & 13 & 14 & 15 & 16 \\
\hline 1 & Integrated EDI & $\begin{array}{l}\mathrm{r}= \\
\mathrm{n}= \\
\mathrm{p}=\end{array}$ & $\begin{array}{c}1.000 \\
- \\
-\end{array}$ & & & & & & & & & & & & & & & \\
\hline 2 & $\begin{array}{l}\text { Integrated Information } \\
\text { Systems }\end{array}$ & $\begin{array}{l}r= \\
n= \\
p=\end{array}$ & $\begin{array}{c}0.360 \\
53 \\
0.008\end{array}$ & $\begin{array}{c}1.000 \\
- \\
-\end{array}$ & & & & & & & & & & & & & & \\
\hline 3 & JIT Manufacturing & $\begin{array}{l}r= \\
n= \\
p=\end{array}$ & $\begin{array}{c}-0.063 \\
55 \\
0.649 \\
\end{array}$ & $\begin{array}{c}0.352 \\
53 \\
0.010\end{array}$ & $\begin{array}{c}1.000 \\
- \\
-\end{array}$ & & & & & & & & & & & & & \\
\hline 4 & JIT Purchasing & $\begin{array}{l}r= \\
n= \\
p=\end{array}$ & $\begin{array}{c}0.041 \\
55 \\
0.768\end{array}$ & $\begin{array}{c}0.311 \\
53 \\
0.023\end{array}$ & $\begin{array}{c}0.540 \\
55 \\
0.000\end{array}$ & $\begin{array}{c}1.000 \\
- \\
-\end{array}$ & & & & & & & & & & & & \\
\hline 5 & Standardization & $\begin{array}{l}r= \\
n= \\
p=\end{array}$ & $\begin{array}{c}0.229 \\
54 \\
0.095 \\
\end{array}$ & $\begin{array}{c}0.382 \\
52 \\
0.005\end{array}$ & $\begin{array}{c}0.420 \\
53 \\
0.002\end{array}$ & $\begin{array}{c}0.309 \\
53 \\
0.024\end{array}$ & $\begin{array}{c}1.000 \\
- \\
-\end{array}$ & & & & & & & & & & & \\
\hline 6 & Supplier Development & $\begin{array}{l}\mathrm{r}= \\
\mathrm{n}= \\
\mathrm{p}=\end{array}$ & $\begin{array}{c}0.217 \\
55 \\
0.112\end{array}$ & $\begin{array}{c}0.090 \\
54 \\
0.518\end{array}$ & $\begin{array}{c}0.200 \\
54 \\
0.148\end{array}$ & $\begin{array}{c}0.272 \\
54 \\
0.046\end{array}$ & $\begin{array}{c}0.274 \\
54 \\
0.045\end{array}$ & $\begin{array}{c}1.000 \\
- \\
-\end{array}$ & & & & & & & & & & \\
\hline 7 & Supplier Partnership & $\begin{array}{l}r= \\
n= \\
p=\end{array}$ & $\begin{array}{c}0.148 \\
55 \\
0.282 \\
\end{array}$ & $\begin{array}{c}0.448 \\
54 \\
.001\end{array}$ & $\begin{array}{c}0.412 \\
55 \\
0.002\end{array}$ & $\begin{array}{c}0.536 \\
55 \\
0.000\end{array}$ & $\begin{array}{c}0.363 \\
54 \\
0.007\end{array}$ & $\begin{array}{c}0.439 \\
55 \\
0.001\end{array}$ & $\begin{array}{c}1.000 \\
- \\
- \\
\end{array}$ & & & & & & & & & \\
\hline 8 & $\begin{array}{l}\text { Cross Functional } \\
\text { Teams for TBC }\end{array}$ & $\begin{array}{l}\mathrm{r}= \\
\mathrm{n}= \\
\mathrm{p}=\end{array}$ & $\begin{array}{c}0.196 \\
56 \\
0.148\end{array}$ & $\begin{array}{c}0.237 \\
54 \\
0.085\end{array}$ & $\begin{array}{c}0.117 \\
55 \\
0.396\end{array}$ & $\begin{array}{c}-0.133 \\
55 \\
0.333\end{array}$ & $\begin{array}{c}0.253 \\
55 \\
0.062\end{array}$ & $\begin{array}{c}0.176 \\
56 \\
0.195\end{array}$ & $\begin{array}{c}0.071 \\
56 \\
0.604\end{array}$ & $\begin{array}{c}1.000 \\
- \\
-\end{array}$ & & & & & & & & \\
\hline 9 & Employee Training - TBC & $\begin{array}{l}r= \\
n= \\
p=\end{array}$ & \begin{tabular}{|c}
0.096 \\
56 \\
0.480
\end{tabular} & $\begin{array}{c}0.201 \\
54 \\
0.146\end{array}$ & $\begin{array}{c}0.298 \\
55 \\
0.027\end{array}$ & $\mid \begin{array}{c}0.211 \\
55 \\
0.122\end{array}$ & $\begin{array}{c}0.122 \\
55 \\
0.376\end{array}$ & $\begin{array}{c}0.049 \\
56 \\
0.721\end{array}$ & $\begin{array}{c}0.133 \\
56 \\
0.328\end{array}$ & $\begin{array}{c}0.665 \\
57 \\
0.000\end{array}$ & $\begin{array}{c}1.000 \\
- \\
-\end{array}$ & & & & & & & \\
\hline 10 & Employee Empowerment & $\begin{array}{l}r= \\
n= \\
p=\end{array}$ & $\begin{array}{c}0.329 \\
53 \\
0.016 \\
\end{array}$ & $\begin{array}{c}0.281 \\
51 \\
0.046\end{array}$ & $\begin{array}{c}0.490 \\
52 \\
0.000\end{array}$ & $\begin{array}{c}0.404 \\
52 \\
0.003\end{array}$ & $\begin{array}{c}0.443 \\
52 \\
0.001\end{array}$ & $\begin{array}{c}0.157 \\
53 \\
0.260\end{array}$ & $\begin{array}{c}0.411 \\
53 \\
0.002\end{array}$ & $\begin{array}{c}0.326 \\
54 \\
0.016\end{array}$ & $\begin{array}{c}0.513 \\
54 \\
0.000\end{array}$ & $\begin{array}{c}1.000 \\
- \\
- \\
\end{array}$ & & & & & & \\
\hline 11 & $\begin{array}{l}\text { Procurement Leadtime } \\
\text { Performance }\end{array}$ & $\begin{array}{l}r= \\
n= \\
p=\end{array}$ & $\begin{array}{c}0.164 \\
56 \\
0.228\end{array}$ & $\begin{array}{c}0.251 \\
54 \\
0.067\end{array}$ & $\begin{array}{c}0.343 \\
55 \\
0.010\end{array}$ & $\begin{array}{c}0.217 \\
55 \\
0.112\end{array}$ & $\begin{array}{c}0.471 \\
55 \\
0.000\end{array}$ & $\begin{array}{c}0.004 \\
56 \\
0.975\end{array}$ & $\begin{array}{c}0.282 \\
56 \\
0.035\end{array}$ & $\begin{array}{c}0.257 \\
57 \\
0.054\end{array}$ & $\begin{array}{c}0.191 \\
57 \\
0.156\end{array}$ & $\begin{array}{c}0.378 \\
54 \\
0.005\end{array}$ & $\begin{array}{c}1.000 \\
- \\
-\end{array}$ & & & & & \\
\hline 12 & Pretax Return on Assets & $\begin{array}{l}r= \\
n= \\
p=\end{array}$ & $\begin{array}{c}-0.215 \\
51 \\
0.131\end{array}$ & $\begin{array}{c}0.049 \\
50 \\
0.733\end{array}$ & $\begin{array}{c}0.138 \\
50 \\
0.340\end{array}$ & $\begin{array}{c}0.341 \\
50 \\
0.015\end{array}$ & $\begin{array}{c}0.284 \\
50 \\
0.046\end{array}$ & $\begin{array}{c}0.245 \\
52 \\
0.081\end{array}$ & $\begin{array}{c}0.197 \\
51 \\
0.166\end{array}$ & $\begin{array}{c}-0.030 \\
52 \\
0.836\end{array}$ & $\begin{array}{c}0.099 \\
52 \\
0.484\end{array}$ & $\begin{array}{c}0.172 \\
50 \\
0.233\end{array}$ & $\begin{array}{c}0.243 \\
52 \\
0.083\end{array}$ & $\begin{array}{c}1.000 \\
- \\
-\end{array}$ & & & & \\
\hline 13 & Aftertax Return on Assets & $\begin{array}{l}r= \\
n= \\
p=\end{array}$ & $\begin{array}{c}-0.219 \\
51 \\
0.122 \\
\end{array}$ & $\begin{array}{c}0.061 \\
50 \\
0.677\end{array}$ & $\begin{array}{c}0.119 \\
50 \\
0.410\end{array}$ & $\begin{array}{c}0.336 \\
50 \\
0.017\end{array}$ & $\begin{array}{c}0.294 \\
50 \\
0.039\end{array}$ & $\begin{array}{c}0.192 \\
52 \\
0.172\end{array}$ & $\begin{array}{c}0.154 \\
51 \\
0.282\end{array}$ & $\begin{array}{c}0.004 \\
52 \\
0.978\end{array}$ & $\begin{array}{c}0.156 \\
52 \\
0.269\end{array}$ & $\begin{array}{c}0.155 \\
50 \\
0.284\end{array}$ & $\begin{array}{c}0.236 \\
52 \\
0.092\end{array}$ & $\begin{array}{c}0.964 \\
52 \\
0.000\end{array}$ & $\begin{array}{c}1.000 \\
- \\
-\end{array}$ & & & \\
\hline 14 & Return on Investments & $\begin{array}{l}r= \\
n= \\
p=\end{array}$ & $\begin{array}{c}-0.180 \\
50 \\
0.212\end{array}$ & $\begin{array}{c}0.122 \\
49 \\
0.403\end{array}$ & $\begin{array}{c}0.118 \\
49 \\
0.420\end{array}$ & $\begin{array}{c}0.199 \\
49 \\
0.170\end{array}$ & $\begin{array}{c}0.275 \\
49 \\
0.056\end{array}$ & $\begin{array}{c}0.110 \\
51 \\
0.442\end{array}$ & $\begin{array}{c}0.107 \\
50 \\
0.461\end{array}$ & $\begin{array}{c}-0.017 \\
51 \\
0.908\end{array}$ & $\begin{array}{c}0.122 \\
51 \\
0.395\end{array}$ & $\begin{array}{c}0.155 \\
49 \\
0.433\end{array}$ & $\begin{array}{c}0.202 \\
51 \\
0.154\end{array}$ & $\begin{array}{c}\mathbf{0 . 8 4 3} \\
51 \\
0.000\end{array}$ & $\begin{array}{c}\mathbf{0 . 8 3 1} \\
51 \\
0.000\end{array}$ & $\begin{array}{c}1.000 \\
- \\
-\end{array}$ & & \\
\hline 15 & Market Share & $\begin{array}{l}r= \\
n= \\
p=\end{array}$ & $\begin{array}{c}0.021 \\
51 \\
0.884\end{array}$ & $\begin{array}{c}0.076 \\
49 \\
0.605\end{array}$ & $\begin{array}{c}0.190 \\
50 \\
0.186\end{array}$ & $\begin{array}{c}0.280 \\
50 \\
0.049\end{array}$ & $\begin{array}{c}0.275 \\
50 \\
0.053\end{array}$ & $\begin{array}{c}0.341 \\
51 \\
0.014\end{array}$ & $\begin{array}{c}0.294 \\
51 \\
0.037\end{array}$ & $\begin{array}{c}-0.139 \\
52 \\
0.325\end{array}$ & $\begin{array}{c}-0.174 \\
52 \\
0.216\end{array}$ & $\begin{array}{c}0.256 \\
49 \\
0.076\end{array}$ & $\begin{array}{c}0.304 \\
52 \\
0.029\end{array}$ & $\begin{array}{c}0.449 \\
50 \\
0.001\end{array}$ & $\begin{array}{c}0.428 \\
50 \\
0.002\end{array}$ & $\begin{array}{c}0.395 \\
49 \\
0.005\end{array}$ & $\begin{array}{c}1.000 \\
- \\
-\end{array}$ & \\
\hline 16 & $\begin{array}{l}\text { Growth in Return } \\
\text { on Investments }\end{array}$ & $\begin{array}{l}r= \\
n= \\
p=\end{array}$ & $\begin{array}{c}-0.047 \\
52 \\
0.742\end{array}$ & $\begin{array}{c}-0.125 \\
51 \\
0.383\end{array}$ & $\begin{array}{c}0.144 \\
51 \\
0.313\end{array}$ & $\begin{array}{c}0.104 \\
51 \\
0.468\end{array}$ & $\begin{array}{c}0.468 \\
51 \\
0.001\end{array}$ & $\begin{array}{c}0.175 \\
53 \\
0.210\end{array}$ & $\begin{array}{c}0.012 \\
52 \\
0.936\end{array}$ & $\begin{array}{c}0.129 \\
53 \\
0.357\end{array}$ & $\begin{array}{c}0.136 \\
53 \\
0.331\end{array}$ & $\begin{array}{c}0.262 \\
51 \\
0.063\end{array}$ & $\begin{array}{c}0.228 \\
53 \\
0.100\end{array}$ & $\begin{array}{c}0.527 \\
52 \\
0.000\end{array}$ & $\begin{array}{c}0.467 \\
52 \\
0.000\end{array}$ & $\begin{array}{c}0.570 \\
51 \\
0.000\end{array}$ & $\begin{array}{c}0.278 \\
50 \\
0.051\end{array}$ & $\begin{array}{c}1.000 \\
- \\
-\end{array}$ \\
\hline 17 & Growth in Market Share & $\begin{array}{l}\mathrm{r}= \\
\mathrm{n}= \\
\mathrm{p}=\end{array}$ & $\begin{array}{c}0.151 \\
54 \\
0.277\end{array}$ & $\begin{array}{c}0.037 \\
52 \\
0.795\end{array}$ & $\begin{array}{c}0.081 \\
53 \\
0.566\end{array}$ & $\begin{array}{c}0.041 \\
53 \\
0.769\end{array}$ & $\begin{array}{c}0.217 \\
53 \\
0.119\end{array}$ & $\begin{array}{c}0.237 \\
54 \\
0.084\end{array}$ & $\begin{array}{c}0.096 \\
54 \\
0.491\end{array}$ & $\begin{array}{c}0.174 \\
55 \\
0.204\end{array}$ & $\begin{array}{c}0.169 \\
55 \\
0.218\end{array}$ & $\begin{array}{c}0.375 \\
52 \\
0.006\end{array}$ & $\begin{array}{c}0.246 \\
55 \\
0.070\end{array}$ & $\begin{array}{c}0.366 \\
52 \\
0.008\end{array}$ & $\begin{array}{c}0.366 \\
52 \\
0.008\end{array}$ & $\begin{array}{c}0.362 \\
51 \\
0.009\end{array}$ & $\begin{array}{c}0.654 \\
52 \\
0.000\end{array}$ & $\begin{array}{c}0.503 \\
53 \\
0.000\end{array}$ \\
\hline
\end{tabular}

Note: Significant correlations $(p<0.05)$ are in bold. 
